Review: Ecology of Marine Phytoplankton

Source: Journal of Ecology, Vol. 1, No. 3 (Sep., 1913), pp. 178-184

Published by: British Ecological Society

Stable URL: http://www.jstor.org/stable/2255334

Accessed: 27-06-2016 09:14 UTC

Your use of the JSTOR archive indicates your acceptance of the Terms \& Conditions of Use, available at

http://about.jstor.org/terms

JSTOR is a not-for-profit service that helps scholars, researchers, and students discover, use, and build upon a wide range of content in a trusted digital archive. We use information technology and tools to increase productivity and facilitate new forms of scholarship. For more information about JSTOR, please contact support@jstor.org.

Wiley, British Ecological Society are collaborating with JSTOR to digitize, preserve and extend access to Journal of Ecology 
community - this is the logical basis of the term plankton. In contrast to the plankton organisms stand the more robust sessile or creeping organisms of the substratum, forming the benthos, and showing no marked adaptations to the specific weight of the water. Benthonic and planktonic members may occur in the same genus (or even the same species, as in Rotifer actinurus); for instance, Oscillatoria Agardhii and Melosira granulata are planktonic, while O. limosa and $M$. varians are benthonic species; in the genus Pediastrum and various others there are definite transitions between planktonic and benthonic forms.

A typical benthọs organism should never be reckoned with the plankton. If one mixes the contents of two beakers, one containing pure plankton and the other well-marked benthos, the mixture cannot be termed plankton. Yet a natural mixture of the two formations occurs in streams and on shores so frequently that the investigator of such waters has before him a "mixtum compositum" difficult of analysis.

The author proposes the term seston for everything that is retained by very fine-meshed sieves; it includes the whole of the material occurring as floating or suspended particles in water, or other liquids, and even in melting ice or snow or in the atmosphere. Since even the purest plankton sample from the clearest waters contains at least a small quantity of detritus particles, it follows that plankton includes only a portion of the floating material while seston embraces the whole. Hence planktonology is strictly speaking a subdivision of "sestonology." In the case of rapidly flowing waters in particular, the total contents of the sieve or net cannot be described as plankton; it is seston, with which more or less plankton is mixed. The catch in such a case might be described as follows: 3 c.c. seston, including 0.5 c.c. of suspended mineral and organic detritus which rapidly settled, while $2 \cdot 5$ c.c. of organisms were deposited gradually and on closer investigation proved to be almost entirely plankton with a small proportion of benthos. The difference in the rate of settling in this case shows clearly the difference between detritus and plankton with regard to specific weight.

\section{ECOLOGY OF MARINE PHYTOPLANKTON}

(I) Ostenfeld, C. H. “De danske farvandes plankton i aarene 1898-1901." Copenhagen, 1913, 364 pages.

(II) Lohmann, H. "Beiträge zur Charakterisierung des Tier und Pflanzenlebens in den von der 'Deutschland' während ihrer Fahrt nach Buenos Ayres durchfahrenen Gebieten des Atlantischen Ozeans." Int. Rev. d. ges. Hydrobiol. u. Hydrogr., 4, 5, 1912, 98 pages.

(I) This important work includes an account of the life conditions and the biology of marine phytoplankton, which though based primarily upon investigations in Danish waters contains much that is of general application.

The organisms constituting the marine phytoplankton are, like all other organisms, influenced by the external medium in which they live and which is represented principally by two groups of factors - the light and the water, the latter comprising a very large number of special factors.

The incident light penetrates the water to a considerable depth but is gradually weakened by absorption and by reflection by the water itself and the solid bodies suspended in it-detritus and plankton. Hence the phytoplankton can only exist in the upper layers of the sea, and investigations made in different parts of the world have shown that the uppermost 100-150 metres contain practically the entire mass of the plankton, but that from about $100-400 \mathrm{~m}$. downwards there exists an impoverished plankton, a "shade flora" largely consisting of species peculiar to itself. However, the water of the oceans is much more transparent than the relatively shallow coastal waters around Denmark, hence one might expect a more limited vertical distribution of the phytoplankton in the latter case. The author found that in the Cattegat a white disc $20 \mathrm{~cm}$. $\times 15 \mathrm{~cm}$. was visible at a maximum depth of about $10 \mathrm{~m}$., while in the Mediterranean the same disc was visible at $35 \mathrm{~m}$., both observations being made in summer. Krümmel, taking the mean of nearly 300 observations, states that a white disc is visible at $9 \mathrm{~m}$. in the Baltic and 
at $13 \mathrm{~m}$. in the North Sea; his disc was somewhat larger than that used by Ostenfeld. The transparency of these north European seas reaches its maximum in August and its minimum in February. Other data are cited, and though the results obtained by different observers vary somewhat, they show that the transparency of these northern waters is but slight, and consequently the plankton is found in the uppermost layers. According to Apstein hardly any living plankton is found in the North Sea below from 75 to $100 \mathrm{~m}$., and the great majority of the organisms occur between the surface and a depth of $40 \mathrm{~m}$.

Interesting results have been obtained at Kiel regarding the variation, conditioned by the seasons, in the intensity and duration of illumination. Lohmann, from observations on the amount of light reaching a free horizontal surface about midday, has calculated the average monthly figure, the length of the day in hours, and lastly the product of these two values-this is permissible since only in this way can one estimate the amount of light which the plankton can utilise. If for December, when the days are shortest and the amount of light at its minimum, the two factors be represented by unity, we find that the value becomes 20 in July. Such a result makes it easy to understand the poverty of the phytoplankton in winter, especially when one bears in mind the fact that this calculation relates to the surface of the water. The following data were obtained by the Prince of Monaco in the roadstead of Funchal (Madeira): the length of the day, as measured by Regnard's apparatus at the end of March, was 11 hours at a depth of $20 \mathrm{~m} ., 5$ hours at $30 \mathrm{~m}$., and only 15 minutes at $40 \mathrm{~m}$.- an extremely rapid diminution determined by the height of the sun and by the increasing reflection and absorption of the light. Pütter and Hertsprung have calculated the quantity of light per day received at Kiel at different times of year. Their figures, expressed in Hefner candle-power per hour per metre from sunrise to sunset, range from 412,000 for June 22 to 10,000 for December 22; the daily average for the year is 150,000 , and the total for the whole year over 71 millions ; according to their calculations the annual amount of light is twice as great at the equator (141 millions) and half as great at the poles (35 millions) as at Kiel. So far as phytoplankton is concerned, the chief interest of these calculations is, of course, the enormous difference between summer and winter, a difference which according to the figures just cited amounts to 40 times-double the result obtained by Lohmann and probably nearer the mark.

The most important of the factors represented by the water are temperature, salinity, and the amount of gaseous and other substances important for the nutrition of the plankton. Salinity and temperature are the best known, since hydrographic investigations consist chiefly in the study of these two factors. Details are given for Danish waters, which form a transition between the brackish Baltic and the salt North Sea, the latter being in turn related to and regulated by the Atlantic. This situation between two very different seas makes the hydrographic conditions very complex, a great exchange and mingling of masses of water taking place in this region. The essential phenomenon is the existence of a current proceeding from the Baltic towards the exterior and a second current proceeding from the North Sea and the Skager Rak towards the interior; the former (Baltic current) is a surface current because of its smaller salt-content, while the latter being richer in salt is a bottom current. Temperature and salinity are the chief factors determining in Danish waters the distribution of the phytoplankton species. While the yearly range of temperature is the essential cause of the annual variation of phytoplankton in each locality, the variable salinity (the degree of which diminishes towards the interior waters) determines the geographical limits of species--the number of species diminishes according as the waters become less saline, but one observes also the appearance of certain species peculiar to brackish waters.

Sea water contains absorbed atmospheric air, and of the three gases present the oxygen and especially the carbon dioxide are absorbed in much larger proportions than the nitrogen. While oxygen represents about 20 per cent. of atmospheric air, in the surface water of the sea over 30 per cent. of the absorbed air is oxygen. The surface water is in general almost saturated with oxygen, but below the surface the proportion of oxygen changes, since this gas is utilised for the respiration of animals and plants while on the other hand the plants liberate oxygen in the process of photosynthesis. Hence the amount of oxygen in sea water out of direct contact with the atmosphere depends on the amount and the nature of the plankton (near coasts and near the bottom it depends also on the vegetation and the animals there present), and it is only in the upper layers, where the phytoplankton finds favourable conditions, that there can be any question 
of an augmentation of oxygen content-below 300-400 m. the water will be always subsaturated. The diminution of oxygen content is related to the length of time during which the water in question has remained far from the surface, and to the quantity of organisms consuming oxygen. As regards the first of these causes, if a mass of water has during a given time and at a given temperature been surface water and has then been covered by another layer of water so that it can no longer take oxygen from the atmosphere, its oxygen content will be diminished by the respiration of animals. The number of these animals is variable, but this variation is in general much less important than the first factor, and hydrographers for this reason utilise the relative oxygen content in their researches on marine currents, though such analyses need to be used with caution. For instance, while the assimilation of phytoplankton can and does modify the oxygen content in the upper layers, to such an extent that sometimes one finds certain layers supersaturated with oxygen (that is, containing more oxygen than they should contain at the existing temperature), the conditions are very complex in the sense that one cannot know whether a given layer of water when it was at the surface had the same temperature that it has later when it is found at a certain depth; if the temperature of this layer has risen after it left the surface, it might be supersaturated without that fact having anything to do with the assimilation of phytoplankton, and conversely if the temperature has fallen the layer might be subsaturated even if it contained no oxygen-consuming organisms.

In the Danish seas the amount of oxygen in the surface water nearly always approaches saturation point, but the oxygen content of the lower layers varies greatly. In the dark winter months of November and February saturation is never observed below the surface, and the oxygen content diminishes as one descends, but the rate of diminution differs according to the seasons and in different regions. In the Cattegat the lower water is somewhat stagnant, and consequently the oxygen content in November falls to 50-60 per cent. below saturation, this water having remained for several weeks without contact with the atmosphere; but in February when the circulation of the water is more active, one finds only about 10 per cent. of subsaturation. In May and in August a supersaturation of as much as 10 per cent. has been found in intermediate layers and even at the bottom in some areas. This supersaturation must be attributed in part at least to the assimilatory activity of the phytoplankton, for it attains its maximum in May in the northern Cattegat and coincides with the maximum Diatom period here; while in August supersaturation is especially marked in the south of the Cattegat, and here again this agrees with observations on the phytoplankton, which at the end of summer consists chiefly of Peridineae showing in these interior waters a particularly intense maximum. Hence there appears to be a well-marked agreement between the relative quantity of oxygen and the periodicity of the plankton.

Owing to the great oxygen-absorbing capacity of water there is probably no question of a lack of oxygen sufficient to inhibit plankton life, but at the same time it must be remembered that the absolute amount of oxygen in a given volume of water is much smaller than in a corresponding volume of air; for while a litre of air contains about 200 c.c. of oxygen, a litre of sea water contains only 6 to 10 c.c. of this gas. Hence marine organisms respire in a medium with much smaller oxygen content than that of the air, but unfortunately very little is known concerning the intensity of the gaseous exchanges connected with respiration and photosynthesis in these organisms. Some experiments made by Vernon showed that the smaller marine animals consume relatively more oxygen than the larger, but of course the relatively large surface of small organisms facilitates the absorption of oxygen since this depends on surface and not on volume. Experiments made by Knudsen and Ostenfeld showed that plankton Diatoms, like other autotrophic plants, consume appreciable quantities of oxygen by respiration in darkness, and give out large quantities of this gas in the course of assimilation in the light.

The conditions under which carbon dioxide is present in sea water are somewhat complex, and little is known concerning those under which the carbon assimilation of the phytoplankton actually takes place. Sea water is usually alkaline in reaction, and apparently carbon dioxide is only exceptionally present in the free state, being either fixed in carbonates or united in looser combination with bicarbonates. The determinations usually made by chemists and hydrographers, indicating simply the percentage of inorganic carbon dioxide in general, do not help much in the consideration of this gas from the point of view of carbon assimilation by the phytoplankton. We may however assume that the members of the phytoplankton assimilate in the same manner 


\section{Ecology of Marine Phytoplankton}

as the higher aquatic plants, and need consider only the (relatively rare) actually free carbon dioxide and that which is loosely combined in bicarbonates; these may for practical purposes be classed as "free" carbon dioxide, in contrast with that which is fixed in carbonates. Various investigators have shown that aquatic vascular plants readily assimilate carbon in water containing dissolved bicarbonates, and that they depend upon the latter rather than upon the actually free dissolved carbon dioxide of the water, but not in solutions of carbonates which are as such not available for plants and only become so when converted into bicarbonates. In his investigations on the tension of carbon dioxide in sea water-that is, the free carbonic acid in the wider sense above suggested-Krogh (1904) made various observations which point to the conclusion that the assimilatory energy of the phytoplankton is in direct ratio to the tension of carbon dioxide. He showed clearly the marked influence which a rich bottom vegetation in relatively shallow seas exerts on this tension, which falls to very low values owing to the assimilation carried on by plants and resulting in the consumption of the free carbon dioxide. Since the phytoplankton uses up considerable amounts of carbon dioxide it is probable that its activity is sometimes threatened by lack of free assimilable carbon dioxide, even if there exist in the water large quantities locked up in combination as carbonates. However, it appears probable that the supply of assimilable carbon dioxide in sea water is constantly being used up and as constantly being renewed from the reserve represented by carbonates - the consumption of this gas disturbs the equilibrium, which is then re-established in this manner.

With regard to soluble organic carbon compounds, the author discusses Pütter's observations and theories concerning the part played by these substances in the nutrition of marine organisms. According to Pütter these compounds are present in the sea in such quantities as to form an important part of the food of various marine animals, which do not depend merely on lower organisms as prey but obtain a large part of their carbon from dissolved organic compounds. This theory challenges the view usually held that the nutrition of the higher marine animals (vertebrates and crustacea) depends upon the direct ingestion of lower forms, and ultimately upon the phytoplankton; but in any case the phytoplankton must be regarded as the only important source of production of organic matter in the sea-hence from this point of view it matters little whether animals devour the phytoplankton organisms directly or assimilate the dissolved organic carbon compounds resulting from the death and decomposition of these organisms. The phytoplankton of course includes various heterotrophic forms, for instance certain colourless Peridineae, and it seems probable that some at any rate of the autotrophic members of the phytoplankton also utilise these dissolved carbon compounds; Richter (1906) showed that certain Diatoms assimilate such compounds in the presence of light. The question largely resolves itself into one of the amount of such compounds actually present in the sea, and various opponents of Pütter's theory have contended that his estimations of the amount of organic carbon are too high. Raben (1909) found that the waters of the Baltic contain extremely small amounts of dissolved organic carbon compounds, though in the neighbourhood of river estuaries there is a larger quantity, owing to the presence of decomposing matter derived from the land.

With regard to the nitrogen dissolved in sea water, it may be assumed that this is as indifferent for the phytoplankton as for the majority of other plants, though indirectly it becomes important from the fact that nitrifying and denitrifying bacteria occur in the sea, which shows a definite nitrogen cycle like that of the soil.

It may be assumed that the same ten essential elements are required for the nutrition of the phytoplankton as for that of other autotrophic plants. The carbon has been already dealt with, the hydrogen and oxygen are of course obtained from the water itself, and of the remaining elements there are relatively abundant quantities of chlorine, magnesium, potassium and sulphur, owing to the large proportion of salts containing these four elements. Since the needs of plants with regard to iron are very limited, this element need not be considered, but there remain the two elements phosphorus and nitrogen, concerning the supply of which in sea water there has been considerable discussion. Recent analyses have shown that the quantity of phosphoric acid in sea water, though very variable, is much lower than had formerly been supposed; in the Baltic it reaches a minimum of $0.15 \mathrm{mgr}$. per litre in winter, while in late summer it rises to $1.4 \mathrm{mgr}$. per litre; in short, it would appear that the inadequate supply of phosphoric acid may considerably limit the amount of the phytoplankton.

Before passing to the question of inorganic nitrogen compounds, it may be noted that besides 
the ten elements already mentioned there are two others which appear to be essential to certain of the phytoplankton organisms at any rate-sodium and silicon. Richter $(1906,1909)$ has shown that for certain Diatoms sodium chloride and silicic acid are essential to life; for the forms investigated (Navicula and Nitzschia) cultures showed an optimum of $1-2$ per cent. sodium chloride, minimum of 0.5 per cent., and maximum of 4 per cent. While there is no question as to the sufficiency of sodium chloride in sea water for the nutrition of the plankton Diatoms, the case is different with regard to silicic acid, which occurs only in small amount. Richter found that this could be assimilated as silicate of either potassium or lime, and that Nitzschia palea, a fresh water species, could not be cultivated in the absence of these substances. Brandt and Raben give the results of numerous careful analyses for the Baltic and the North Sea, in which the average is about $0.75 \mathrm{mgr}$. per litre; the proportion varies with the seasons, with a minimum in May - that is, immediately after the Diatom maximum, probably indicating that the cessation of the Diatom maximum in spring is caused in part at any rate by lack of silicic acid.

Inorganic compounds of nitrogen (ammonium salts, nitrites and nitrates) are present only in very small amount in sea water. Allen and Nelson (1910) found that it was necessary to add to sterilised sea water a salt containing nitrogen in order to keep a culture of Diatoms alive and growing for more than a very short period. Raben's analyses for the Baltic and the North Sea give very variable results, but in both seas the average amount of nitrogen in the form of ammonia is about $0.07 \mathrm{mgr}$. per litre, and that of nitrogen in the form of nitrite and nitrate $0.12 \mathrm{mgr}$. per litre; in February and May considerably higher values were obtained, especially for nitrite and nitrate, than in August and November. There can be little doubt that putrefying, nitrifying and denitrifying bacteria play determining parts in the question of the amount of nitrogen compounds contained in sea water, which may indeed depend largely upon the distribution of these various bacteria in different regions.

In the section devoted to the biology of the phytoplankton, the author deals with the life cycle of the two chief groups Diatomeae and Peridineae and the less important groups Flagellata and Cyanophyceae, adaptations to plankton life, periodicity, and plankton communities.

The Diatoms reproduce themselves by rapid division during the phase of active growth, while various types of resting spores are formed (all usually termed auxospores though produced in very different ways); the so-called microspores found in some cases are possibly male gametes which fuse with ordinary cells to form auxospores. The great majority of the neritic species (those of coastal waters) are meroplanktonic, disappearing from the plankton (though persisting as resting spores) after their period of active growth, but a few are holoplanktonic, i.e. to be found throughout the year in the active condition; while others, during the period when they are not suspended in the plankton, live attached to plants or rocks at the bottom-these are termed tychopelagic. In contrast with the neritic species, the oceanic species (those found in the open waters of the ocean) are apparently all holoplanktonic.

The Peridineae, unlike the Diatoms, move by means of a pair of motile flagella, and the cellmembrane is devoid of silica. The dominant genus is Ceratium, all the species of which are autotrophic and holoplanktonic, and the most important species being C. tripos. This and other species have been studied in great detail; division occurs during the night and takes place at the rate of from 20 to 50 per cent. daily - that is, under favourable conditions and at the time of most rapid division the number of individuals is doubled in from 2 to 5 days. Next to Ceratium in importance comes the genus Peridinium, in which the majority of the species are holoplanktonic and heterotrophic, having no chromatophores, though some are neritic and autotrophic.

The most obvious adaptations to plankton conditions are those related to the necessity for the organisms to remain suspended in the water, or more precisely to have a very slight rate of fall. Among the chief phytoplankton organisms, the Diatoms and the Cyanophyceae are motionless, whereas the Peridineae are motile by means of their flagella-though the distances these organisms can traverse by this means are so slight that their faculty of suspension in the water is due to these motile organs in only a very slight degree. The faculty for remaining suspended in the water is conditioned by three factors-(1) specific gravity, i.e. the difference between the weight of the organism and that of the water it displaces; (2) resistance due to form, i.e. the resistance which the organism owing to its external configuration opposes to fall; (3) viscosity, i.e. the tenacity with which the water particles cohere and thus oppose the entry of foreign 


\section{Ecology of Marine Phytoplankton}

bodies. The viscosity of sea water is greater than that of fresh water, and it depends on the temperature-the rate of fall is twice as great at $25^{\circ} \mathrm{C}$. as at $0^{\circ} \mathrm{C}$., hence the warmer and less saline the water the greater must be the faculty of suspension in order to resist the tendency to fall. Phytoplankton organisms are adapted in two different directions for the diminution of rate of fall-(1) slight weight, (2) great resistance of form. Reduction in weight is brought about by small size, i.e. large surface in proportion to volume; thin walls; the disposition of the protoplasm in a parietal layer, the centre of the cell being occupied by cell-sap, i.e. the organism has a large volume in proportion to its contents; assimilation products (oils) lighter than water; gas vacuoles in Cyanophyceae, etc. Resistance of form is increased by enlargement of the surface by elongation or flattening; curvature or asymmetry of the cell of such a nature that in its slow descent the cell changes its position until it reaches a position of equilibrium; development of prolongations, outgrowths, and other flotation mechanisms; formation of colonies, the colony or chain showing adaptations of the same kind as the individual cells; and the development of a mucous investment around the cell or colony. The relation between the viscosity of water and its temperature, already mentioned, makes it probable is priori that the plankton of warm waters should be better provided with flotation mechanisms than those of cold waters; and in general this is the case. Moreover, this should apply also to the summer plankton as compared with the winter plankton of the same region, assuming that other factors remain unchanged; and though relatively few observations have been made from this point of view there are certainly some cases. where the same species (e.g. Ceratium furca in the Black Sea) appears as long slender cells in summer and as short thick cells in winter.

The meroplanktonic organisms appear in the plankton only at a certain period of the year, during which they increase, reach their maximum, and then decrease-some have two maxima; while the holoplanktonic forms are always found in the plankton though not always in equal amount-they also have a maximum. Plankton researches have determined the seasons when the most important species appear or attain their maximum, and it is found that for each species this occurs at approximately the same time of the year-not necessarily according to the calendar but from the biological point of view. That is, the periods of appearance and maximum of the various species succeed each other in the same order year by year. For instance a late spring, i.e. a delayed rise of water temperature, results in retarded appearance of the spring forms, but the summer types are also retarded.

The great majority of the neritic Diatoms of the area investigated have their active period in spring, and for most of the others this period occurs in late summer and in autumn-only a few reach their maximum in midsummer or in winter; while others again have a maximum in spring and a second in autumn - the author suggests the term diacmic for these forms, while those with a single maximum are termed monacmic. Nearly all the Peridineae show a summer maximum.

Though a vast amount of information concerning the periodic phenomena of phytoplankton has accumulated, the causes of periodicity have not yet been fully elucidated. These causes are partly external and partly internal; just as, for instance, an Anemone grows and flowers in spring under suitable conditions of light, temperature, etc., but not in autumn, though the external conditions are then apparently about the same as in spring, so a plankton Diatom "flowers" at a certain time of year and then disappears (i.e. passes into a resting condition as spores) and does not reappear until the corresponding period of the following year. Obviously in both cases the periodicity is not determined solely by the external factors-the internal condition of the organism must be taken into account.

The most important external factors are probably temperature and light. Since several species have approximately the same requirements, and consequently appear simultaneously, it follows that in the course of the year one plankton community succeeds another, much in the same way that in a wood one type of undergrowth replaces another during spring and summer, the composition and order of succession of the communities remaining apparently the same from year to year. In the Danish seas in spring one community of Diatoms succeeds another, then in summer appear the communities of Peridineae, and in autumn communities of Diatoms again. The author promises for future publication a more detailed investigation of plankton communities.

(II) The author gives the results of plankton investigations carried on during five months (May to September) in the Atlantic Ocean between $50^{\circ} \mathrm{N}$. and $40^{\circ} \mathrm{S}$. - the area being thus divided 
into a northern and a southern cold water zone and a tropical zone between these. The tropical plankton was found to be poorer in number of organisms but richer in species than that of cooler waters. The Coccolithophoridae play an important part in all parts of the ocean, and the Peridineae are also widely distributed, while the Trichodesmieae (belonging to the family Oscillatoriaceae of blue-green algae) are exclusively tropical. On the other hand the Diatoms and the naked Phytoflagellata predominate in the cooler zones; the former are more numerous in the north, the latter in the south. In the zone three regions are distinguished both hydrographically and biologically-the northern region (Sargasso Sea and north equatorial current), the Guinea current, and the southern region (south equatorial current and Brazil current). The median portion of the Sargasso Sea showed a fair abundance of Coccolithophoridae, which fell off in numbers towards the margin of this sea and were found very sparingly in the Guinea current. In the latter were found abundant Trichodesmieae, also a Euglena, a Prorocentrum (Peridineae), and the Tunicate animal Oikopleura dioica-the last three organisms are apparently characteristic of this current, while Trichodesmium is also common in the north equatorial current but was not found in the south tropical region, where there were obtained enormous quantities of Coccolithophoridae belonging to species which were either new or had previously been found only sparingly. In the Brazil stream these organisms were accompanied by Diatoms, of which one (Brenneckella Lorenzeni) apparently lives in symbiosis with the Coccolithophorid Pontosphaera sessilis.

With regard to the vertical distribution of the plankton, in the cold water zones the maximum occurred near the surface, while in the tropics it was at about $50 \mathrm{~m}$. depth; but a remarkable exception to this rule was found in the regions rich in Trichodesmium where this alga formed extensive floating masses at the surface. On the whole the ecological temperature optimum for the phytoplankton in the tropical zone lies in the deeper water; in the cold water zones the uppermost $100 \mathrm{~m}$. contain $80-90$ per cent. of this plankton, in the tropics less than 70 per cent. The author gives descriptions of a large number of new plankton forms, with special reference to their adaptations for flotation. Perhaps the most interesting result of the investigation-in which the most effective methods of centrifugal separation, etc., were employed-is that relating to the Coccolithophoridae; this group, the knowledge of which has grown rapidly during recent years, proves to have quite as varied and remarkable flotation mechanisms as those found in the Diatoms.

\section{NITROGEN-FIXATION BY AZOTOBACTER CHROOCOCCUM}

Mockeridge, Florence A. "Some conditions influencing the fixation of nitrogen by Azotobacter and the growth of the organism." Anrals of Botany, 26, 1912, pp. $871-887$.

Since nitric acid is practically the only form in which higher plants obtain the nitrogen they require, the fertility of the soil is closely related to the maintenance by soil organisms of the nitrogen cycle of change, and these organisms have received a very large amount of attention. The organic nitrogenous compounds, largely proteins, are broken down by soil bacteria into simpler compounds, like the amino-acids, and these into ammonia which in turn is oxidised successively into nitrous and nitric acid by other organisms. Under certain conditions, still other organisms come into play and by their action the nitrogenous compounds are converted into free nitrogen gas and thus lost to the soil; while on the other hand another group of organisms cause the fixation of free nitrogen, combining it with oxygen, hydrogen, carbon, etc., into forms available for higher plants.

Among the nitrogen-fixing organisms, some, as is well known, live in symbiosis with green plants (Leguminosae, etc.), the bacteria obtaining the carbohydrate they must consume from the higher plant which is supplied by them with combined nitrogen. Of the nitrogen-fixing organisms living free in the soil, the most fully investigated are Clostridium Pasteurianum and Azotobacter chroococcum, both very widely diffused in the soil. The former is readily isolated from pond mud and other soils in which organic matter is decaying under more or less anaërobic conditions; but the extent of the nitrogen-fixation which it effects is relatively small-in the 